
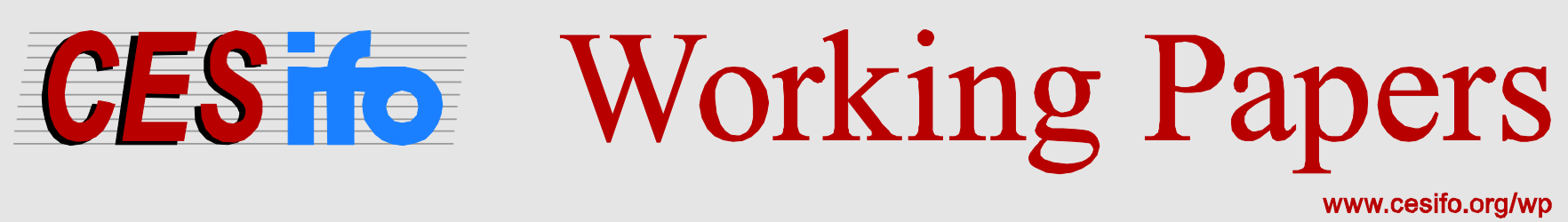

\title{
The Weight of Inequality: Variation with Industrialization and Wealth
}

\author{
Scott Alan Carson
}

\section{CESIFO WORKING PAPER NO. 5629 \\ CATEGORY 4: LABOUR MARKETS \\ NOVEMBER 2015}
An electronic version of the paper may be downloaded
- from the SSRN website: Www.SSRN.com
- from the RePEc website: Www.RePEc.org
- from the CESifo website: www.CESifo-group.org/wp




\title{
The Weight of Inequality: Variation with Industrialization and Wealth
}

\begin{abstract}
When other economic measurements are scarce or unreliable, height and the body mass index (BMI) are now well accepted measures for cumulative and current net nutrition. However, as the ratio of weight to height, BMI is the ratio of current to cumulative net nutrition, therefore, does not fully isolate changes in current net nutrition. This study uses weight after controlling for height as a measure for current net nutrition and shows that US black and white weights decreased throughout the late 19th and early 20th centuries, were higher in the South, and for farmers and unskilled workers. Like stature and BMI, 19th century weight was higher in states with greater average wealth and population density and lower in states with greater wealth inequality.
\end{abstract}

JEL-Codes: I100, J110, J710, N310.

Keywords: weight, current net nutrition, wealth, inequality.

Scott Alan Carson

University of Texas, Permian Basin

4901 East University

USA - Odessa, TX 79762

Carson_S@utpb.edu

I appreciate comments from John Komlos, Lee Carson, and Paul Hodges. Shahil Sharma, Chinuedu Akah, Meekam Okeke, Ryan Keifer, Tiffany Grant, Bryce Harper, Greg Davis, Kellye Manning, and Brandon Hayes provided research assistance. 


\section{The Weight of Inequality: Variation with Industrialization and Wealth}

\section{Introduction}

When traditional measures for economic welfare are scarce or unavailable, stature and body mass index (BMI) values are now well accepted measures for material well-being (Fogel, 1994; Deaton, 2008; Case and Paxson, 2008; Deaton, 2013). Stature represents the cumulative net difference between calories consumed, less calories required for work and to fend off disease. $\mathrm{BMI}$ is weight in kilograms divided by height in meters squared, and changes in BMIs are interpreted as reflecting changes in current net nutrition (Fogel, 1994, pp. 371-373). Nevertheless, because it does not distinguish between muscle, sinew, and bone, BMI remains

only a course measure for obesity (Burkhauser and Cawley, 2008, pp. 519-520). In both historic and modern samples, BMI is also the primary means of classifying obesity. However, interpreting BMI variation is more problematic than interpreting stature variation because current BMIs also reflect early life conditions. For example, if an individual is poorly nourished in their youth, they may reach shorter terminal statures (Steckel, 1995), their frames may not fully develop, leading to shorter statures and lower metabolic rates in older ages (Mifflin et al. 1990). If their nutrition improves in later life, they may be more likely to be obese because their weight is distributed over smaller physical dimensions (Herbert et al., 1993, pp. 1438; Carson, 2009a; Carson, 2012a; Sorkin et 1999; Sorkin et al., 1999). On the other hand, if a person receives adequate nutrition during their adolescent years, they reach taller statures, and since their weight is distributed over larger frames, taller statures may be associated with lower BMI values. 
There are, however, alternative measures for BMI that reflect current net nutrition, such as weight after controlling for height. Since weight varies more than height with current conditions, weight provides important insight into how current net nutrition varies over time, across ethnicity, and by socioeconomic status (Dawes, 2014, p. 30). Like stature and BMI, weight varies with age, ethnic status, socioeconomic status, residence, and overtime; however, little is known about how $19^{\text {th }}$ century weight varied with wealth inequality, family size, and population density (Carson, 2015b). To isolate how current net nutrition was related to economic conditions, this study uses late $19^{\text {th }}$ and early $20^{\text {th }}$ century weight and height records from multiple state prisons to consider how weight varied by demographic characteristics, socioeconomic status, residence, wealth, and inequality.

It is against this backdrop that this study considers three paths of inquiry into late $19^{\text {th }}$ and early $20^{\text {th }}$ century US black and white weights during economic development. First, how did individual weights vary with wealth accumulation and inequality? Weight increased in wealth at a decreasing rate and was lower in states with greater inequality. Second, how did weights vary with family size? Nineteenth century weights increased with family size, indicating that additional family members increased household wealth, offsetting increases in additional demands on household resources (Becker, 1981, pp. 97 and 102). Third, how did weights vary with population density and urbanization? Weight increased with population density at a decreasing rate, and close proximity to high population density centers was associated with lower weights.

\section{Nineteenth Century U.S. Prison Diets and Weight Data}

Weight is an important health measure for current net nutrition that reflects many health conditions related to changes in economic conditions and diets. Weight also reflects the current 
net nutrition available to a population. Nineteenth century US diets were relatively plentiful, and annual white diets averaged around 184 pounds of meat, 15 pounds of butter, 13 pounds of lard, and 205 pounds of wheat (Cummings, 1940). Nineteenth century diets and calories varied regionally, and Atack and Bateman (1987) consider $19^{\text {th }}$ century northern white diets and find that Northerners annually consumed about 200 pounds of meat, 770 pounds of fluid milk, butter, and cheese, and 13.5 bushels of grain. Shergold (1982, pp. 185-195), Hilliard, (1972, pp. 135 and 166), and Comer (2000, p. 1315) find that Northeastern diets were high in dairy products, grains, and breads. Southern diets were more diverse than northern diets, and meat was more readily available in the South (Hilliard, 1972, pp. 112-140). Part of the Southern nutrition advantage was related to greater agricultural productivity (Fogel and Engerman, 1974, p. 193); however, after emancipation, Southern food production decreased (Ransom and Sutch, 1977, pp. 151-156). In sum, late $19^{\text {th }}$ century US nutrition varied regionally, and how net nutrition varied with family size, wealth, and urbanization reflects nutritional conditions during early economic development.

The two most common sources of historical weight and height data are military and prison records. Military records represent conditions among the upper class, while prison records represent conditions among the working class (Sokoloff and Vilaflour, 1982). One potential problem associated with military weights is a minimum stature requirement for service that omits enlistees below a given stature, typically 64 inches. This stature truncation may influence military weights because weight is related to height and by truncating recruits with shorter statures means that only taller individuals with lower BMIs remain in military samples (Herbert et al., 1993, p. 1438; Carson, 2009a; Carson, 2012a). Prisoners are an alternative to soldiers; however, when used as a measure for current net nutrition, prison data have their own 
disadvantages. For example, it is not clear which social class prisoners represent because law enforcement officials may have incarcerated many of the materially poorest individuals who did not reach their genetically predetermined statures. ${ }^{1}$ On the other hand, if law enforcement officials inferred guilt from larger physical size, prison enumerators may have incarcerated many of the tallest, most physically fit individuals involved in crime. However, there is no systematic relationship between heights and the various crimes for which individuals were incarcerated (Carson, 2005, p. 411; Carson, 2007, p. 44).

Prison enumerators were thorough when recording inmate complexions, and white inmate complexions were recorded as fair, light, medium, and dark. Black inmate complexions were recorded as black, light-black, dark-black, and various shades mulatto. Throughout this manuscript, individuals recorded as mulattos in the original prison registries are referred to as mixed race here. Although these mixed race individuals shared genetic characteristics with both blacks and whites, they were treated as blacks in the $19^{\text {th }}$ century US, and when appropriate, are grouped here with blacks. Enumerators recorded various occupation categories which are classified here as white-collar, skilled, farmers, unskilled, and workers with no listed occupations. Highly skilled workers, bankers, and merchants are classified as white collar workers; blacksmiths, carpenters, and craft workers are classified as skilled workers; farmers, dairy workers, and ranchers are classified as farmers. Laborers and miners are classified as unskilled workers. Prison enumerators typically did not distinguish between farm and common laborers; however, the distinction is important because urban workers encountered less favorable

\footnotetext{
${ }^{1}$ There has been considerable attention given to potential biases caused from using military and prison records to assess the antebellum and early industrial growth paradox. However, the critique has not been well supported. http://aez.econ.northwestern.edu/zimran_height_selection.pdf
} 
biological conditions, while farm laborers encountered better net nutritional conditions, which likely understates the biological benefits of being a farm laborer and overstates the biological advantages that accrued to common laborers (Carson, 2013; Carson, 2015a). Between 1840 and 1920, prison guards typically recorded an individual's age, the date of entry, nativity, complexion, stature, weight, pre-incarceration occupation, and crime. Because wealth, inequality, and family size were only recorded in the 1860 and 1870 censuses, the prison data are restricted to observations between 1855 and 1874 .

Three existing studies that shed light on historical weights are Komlos (1987), Komlos and Coclanis (1995), and Carson (2015b). For West Point cadets, Komlos (1987) demonstrates that $19^{\text {th }}$ century weights decreased, which was experienced across the US and was experienced by farmers and unskilled workers. Coclanis and Komlos (1995, p. 104) support this finding by using late $19^{\text {th }}$ and early $20^{\text {th }}$ century student records at the Citadel to show that weights decreased throughout the late $19^{\text {th }}$ century. Carson (2015b) shows that US weights decreased throughout the $19^{\text {th }}$ century, were greater in the South, and were higher for workers in agricultural occupations. Historical weight studies have otherwise received little attention. Nothing is known, however, about how $19^{\text {th }}$ century black and white weight varied by wealth inequality, and population density. 
Table 1, Nineteenth Century Black and White Demographics and Socioeconomic Status

\begin{tabular}{|c|c|c|c|c|}
\hline & Blacks & & Whites & \\
\hline & $\mathrm{N}$ & Percent & $\mathrm{N}$ & Percent \\
\hline \multicolumn{5}{|l|}{ Ages } \\
\hline Teens & 1,062 & 23.01 & 871 & 19.61 \\
\hline $20 s$ & 2,604 & 56.41 & 2,469 & 55.58 \\
\hline $30 \mathrm{~s}$ & 575 & 12.46 & 710 & 15.98 \\
\hline $40 \mathrm{~s}$ & 236 & 5.11 & 250 & 5.63 \\
\hline $50 \mathrm{~s}$ & 113 & 2.45 & 116 & 2.61 \\
\hline $60 \mathrm{~s}$ & 24 & .52 & 20 & .45 \\
\hline $70 \mathrm{~s}$ & 2 & .04 & 6 & .14 \\
\hline \multicolumn{5}{|l|}{ Birth Decade } \\
\hline $1800 s$ & 9 & .19 & 28 & .63 \\
\hline $1810 \mathrm{~s}$ & 93 & 2.01 & 113 & 2.54 \\
\hline $1820 s$ & 168 & 3.64 & 216 & 4.86 \\
\hline 1830s & 437 & 9.47 & 614 & 13.82 \\
\hline 1840s & 1,686 & 36.43 & 1,763 & 39.69 \\
\hline 1850s & 2,188 & 47.40 & 1,706 & 38.41 \\
\hline $1860 s$ & 35 & .76 & 2 & .05 \\
\hline \multicolumn{5}{|l|}{ Observation } \\
\hline \multicolumn{5}{|l|}{ Decade } \\
\hline $1860 \mathrm{~s}$ & 980 & 21.23 & 1,307 & 29.42 \\
\hline $1870 s$ & 3,636 & 78.77 & 3,135 & 70.58 \\
\hline \multicolumn{5}{|l|}{ Occupations } \\
\hline White-Collar & 55 & 1.19 & 115 & 2.59 \\
\hline Skilled & 219 & 4.74 & 793 & 17.65 \\
\hline Farmers & 13 & .28 & 18 & .41 \\
\hline Unskilled & 2,452 & 53.12 & 2,299 & 51.76 \\
\hline No & 1,877 & 40.66 & 1,217 & 27.40 \\
\hline \multicolumn{5}{|l|}{ Occupation } \\
\hline \multicolumn{5}{|l|}{ Nativity } \\
\hline Northeast & 157 & 3.40 & 870 & 19.59 \\
\hline Middle & 177 & 3.83 & 509 & 11.46 \\
\hline \multicolumn{5}{|l|}{ Atlantic } \\
\hline Great Lakes & 58 & 1.26 & 352 & 7.92 \\
\hline Southeast & 3,845 & 83.20 & 2,451 & 55.18 \\
\hline Southwest & 300 & 6.50 & 138 & 3.11 \\
\hline Far West & 2 & .04 & 2 & .05 \\
\hline \multicolumn{5}{|l|}{ Residence } \\
\hline Kentucky & 1,530 & 33.15 & 1,991 & 44.82 \\
\hline
\end{tabular}




\begin{tabular}{l|cccc}
\hline Oregon & 3 & .06 & 30 & .68 \\
Philadelphia & 273 & 5.91 & 1,078 & 24.27 \\
Tennessee & 1,825 & 39.54 & 818 & 18.42 \\
Texas & 985 & 21.34 & 525 & 11.82 \\
& 4,616 & 100.00 & 4,442 & 100.00 \\
\hline
\end{tabular}

Source: Date used to study anthropometrics is a subset of a much larger $19^{\text {th }}$ century prison sample. All available records from American state repositories have been acquired and entered into a master file. These records include Arizona, California, Colorado, Idaho, Illinois, Kansas, Kentucky, Missouri, New Mexico, Ohio, Oregon, Pennsylvania, Tennessee, Texas, Utah and Washington.

Notes: Prisons used in this study are restricted to states that recorded weight that can be linked to average state values.

Blacks were incarcerated at younger ages, and whites were incarcerated and older ages (Hirschi and Gottfredson, 1983; Carson, 2009a). Whites made up a larger portion of the early $19^{\text {th }}$ century prison population, but with emancipation and passage of the $13^{\text {th }}$ Amendment, African-Americans made up a larger portion of the prison population. Before emancipation, slave masters had claims on slave labor, but incarceration prevented slave-owners from earning returns on their slave property. Early Southern laws, therefore, evolved to allow owners to punish their slaves on their plantations while slaves worked to pay the social costs of their crimes (Wahl, 1996; Wahl 1997). However, with emancipation, slave owners no longer had claims on slave labor, and blacks who broke the law were more likely to be incarcerated after emancipation. There were more whites in US prisoners than blacks; however, blacks are overrepresented in the prison population relative to whites in the general population. 
Figure 1, Late $19^{\text {th }}$ and Early $20^{\text {th }}$ Century Black and White Male Weight
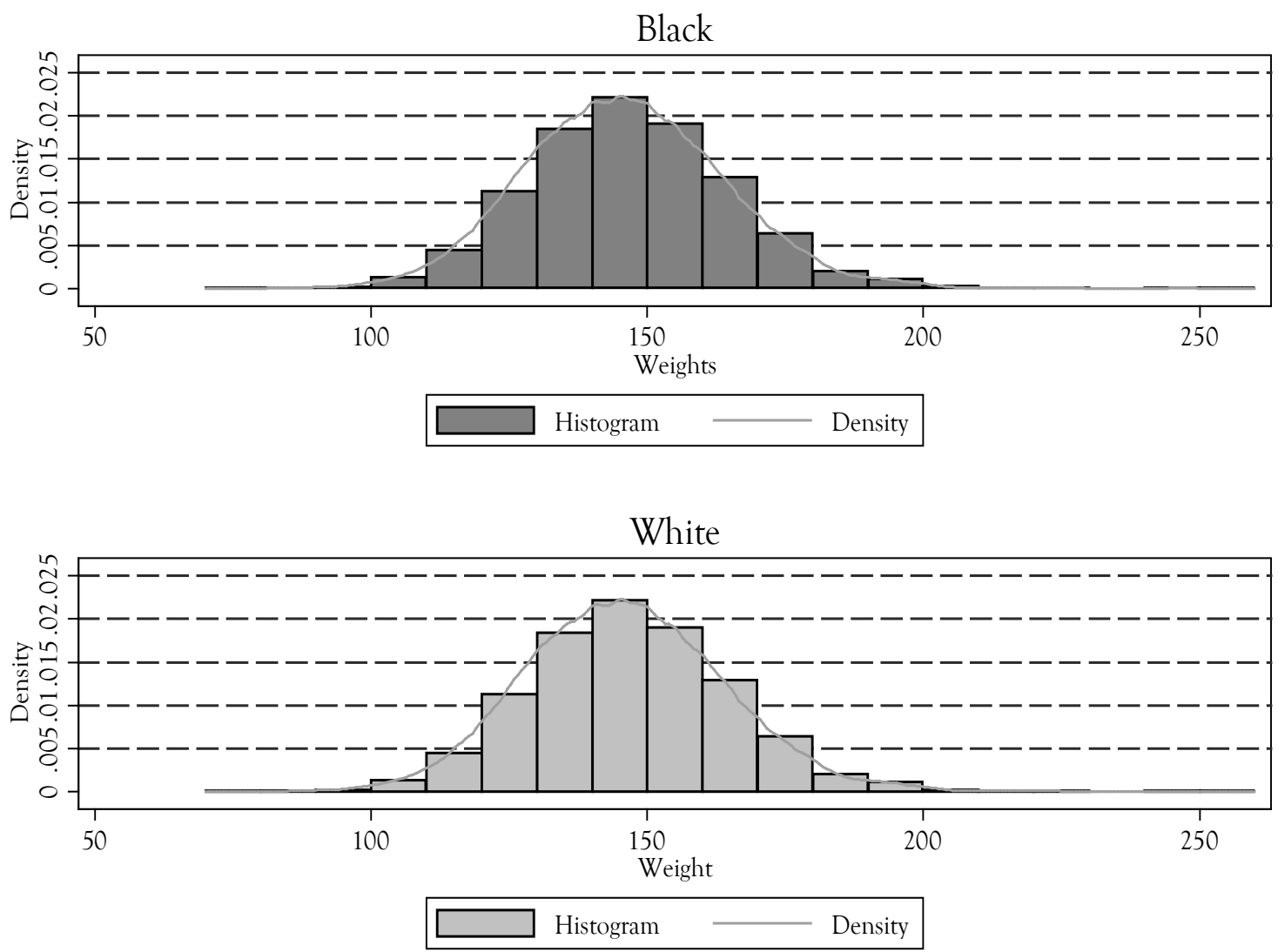

Source: See Table 1.

A population's weight distribution provides insight on its current net nutrition. If a weight distribution is negatively skewed, there is a disproportionate number of underweight individuals, Figure 1 presents weight kernel density estimates and illustrates that weight distributions were nearly symmetric. For current net nutrition, black and white men were neither starved nor did they live in choleric abundance. Average black weight was 151.20 pounds, and average black height was 66.67 inches. Average white weight was 145.95 pounds, and white average height was 67.52 inches, indicating that blacks were short and heavy, while whites were tall and thin. 


\section{Nineteenth Century Black and White Weight Variation}

We now test how heights, demographics, and material conditions were associated with late $19^{\text {th }}$ and early $20^{\text {th }}$ century US weights. To start, weights are regressed on height, complexion, age, occupation, wealth, inequality, population density, nativity, birth decades, and family size.

$$
\begin{aligned}
& \text { Weight }_{i}=\alpha+\beta_{I} \text { Inch }_{i}+\sum_{p=1}^{2} \beta_{p} \text { Complexion }_{i}+\sum_{a=1}^{15} \beta_{a} \text { Age }_{i}+\beta_{l} \text { Farmers \& Laborers } \\
& +\beta_{T W} \text { Total Wealth }_{i}+\beta_{T W^{2}} \text { Total Wealth }_{i}^{2}+\beta_{G} \text { Wealth Gini }_{i}+\beta_{P D} \text { Population Density }_{i} \\
& +\beta_{P D^{2}} \text { Population Density }_{i}^{2}+\sum_{n=1}^{6} \beta_{n} \text { Nativity }_{i}+\sum_{b=1}^{5} \beta_{b} \text { Birth Decade }_{i} \\
& +\beta_{F S} \text { Family Size }_{i}+\beta_{F^{2}}^{2} \text { Family Size }_{i}^{2}+\varepsilon_{i}
\end{aligned}
$$

Weight in pounds is regressed on height in inches to account for the relationship between cumulative net nutrition. Dark and light black complexion dummy variables are included to account for how weight varied with complexion. Youth age dummy variables are included for ages 14 through 22; adult age dummies are included in ten year age intervals from age 30 through their 70s. To account for how height varied with socioeconomic status, an occupation dummy variable is included for farmers and unskilled occupations. State level wealth and Gini coefficients are included to account for the relationship between weight, wealth, and inequality. Wealth and inequality may also be related to urbanization, and state population density variables are included to account for the relationship between weight and urbanization. To assess how weight varied throughout the $19^{\text {th }}$ century, birth decade dummy variables are included in ten year intervals from 1800 through 1850 . Family size and family size squared variables are included to account for the relationship between weight and family size. 
Table 2's model 1 includes black and white BMIs to account for how BMIs varied with observable characteristics. Model 2 demonstrates how black and white weight varied with the same characteristics. To illustrate how the percentage change in weight varied with observable characteristics, Model 3 presents the same model with the natural log of weight as the dependent variable. Model 4 accounts for how black weight varied in levels with demographic, socioeconomic, and wealth characteristics, while Model 5 does the same for whites. Models 6 and 7 consider the weight relationship between youths and adults.

Table 2, Nineteenth Century Weight by Demographics, Socioeconomic Status, Wealth, and Inequality

\begin{tabular}{|c|c|c|c|c|c|c|c|}
\hline & $B M I$ & $\begin{array}{c}\text { Total } \\
\text { Weight }\end{array}$ & $\begin{array}{c}\text { Total, } \\
\ln (\text { weight })\end{array}$ & $\begin{array}{c}\text { Black } \\
\text { Weights }\end{array}$ & $\begin{array}{c}\text { White } \\
\text { Weights }\end{array}$ & $\begin{array}{c}\text { Youth } \\
\text { Weights }\end{array}$ & $\begin{array}{c}\text { Adult } \\
\text { Weights }\end{array}$ \\
\hline & Model 1 & Model 2 & Model 3 & Model 4 & Model 5 & Model 6 & Model 7 \\
\hline $\begin{array}{l}\text { Intercept } \\
\text { Height }\end{array}$ & $34.39 * * *$ & $-81.91 * * *$ & $3.43 * * *$ & $-73.74 * * *$ & $-89.80 * * *$ & -31.31 & $-91.88 * * *$ \\
\hline $\begin{array}{l}\text { Inches } \\
\text { Ethnicity }\end{array}$ & $-.177 * * *$ & $3.37 * * *$ & $.023 * * *$ & $3.38 * * *$ & $3.38 * * *$ & $3.20 * * *$ & $3.45^{* * *}$ \\
\hline White & Reference & Reference & Reference & & & Reference & Reference \\
\hline Black & $1.23^{* * *}$ & $8.07 * * *$ & $.054 * * *$ & Reference & & $5.81 * * *$ & $9.30 * * *$ \\
\hline $\begin{array}{l}\text { Mixed-race } \\
\text { Ages }\end{array}$ & $.861 * * *$ & $5.64 * *$ & $.037 * * *$ & -1.70 & & $5.12 * * *$ & $5.97 * * *$ \\
\hline 14 & $-3.16 * * *$ & $-17.67 * * *$ & $-.142 * * *$ & $-19.25 * * *$ & $-14.21 * * *$ & $-17.03 * * *$ & \\
\hline 15 & $-3.10 * * *$ & $-18.33 * * *$ & $-.143 * * *$ & $-18.91 * * *$ & $-17.28 * * *$ & $-17.65 * * *$ & \\
\hline 16 & $-2.31 * * *$ & $-13.94 * * *$ & $-.105 * * *$ & $-16.08 * * *$ & $-10.84 * * *$ & $-13.09 * * *$ & \\
\hline 17 & $-1.44 * * *$ & $-8.84 * * *$ & $-.064 * * *$ & $-9.36 * * *$ & $-8.15 * * *$ & $-7.89 * * *$ & \\
\hline 18 & $-1.30 * * *$ & $-8.10 * * *$ & $-.056 * * *$ & $-9.90 * * *$ & $-6.10 * * *$ & $-7.05 * * *$ & \\
\hline 19 & $-.650 * * *$ & $-4.27 * * *$ & $-.028 * * *$ & $-5.45 * * *$ & $-3.26 * * *$ & $-3.14 * * *$ & \\
\hline $20 s$ & Reference & Reference & Reference & Reference & Reference & Reference & Reference \\
\hline $30 \mathrm{~s}$ & $.222 * * *$ & $1.45 * *$ & $.009 * *$ & 1.04 & $1.75^{* *}$ & & $1.25 *$ \\
\hline $40 \mathrm{~s}$ & $.495 * * *$ & $3.27 * *$ & $.020 * * *$ & $4.76 * * *$ & 1.65 & & $3.12 * * *$ \\
\hline $\begin{array}{l}\text { 50s } \\
\text { Occupations }\end{array}$ & .363 & 1.99 & .013 & 3.58 & .263 & & 1.97 \\
\hline $\begin{array}{l}\text { Non- } \\
\text { Farmers }\end{array}$ & Reference & Reference & Reference & Reference & Reference & Reference & Reference \\
\hline $\begin{array}{l}\text { Farmers and } \\
\text { Laborers }\end{array}$ & $.168 * * *$ & $1.06 * *$ & $.008 * * *$ & .950 & .892 & .869 & .996 \\
\hline
\end{tabular}




\begin{tabular}{|c|c|c|c|c|c|c|c|}
\hline $\begin{array}{l}\text { Wealth } \\
\text { Total }\end{array}$ & -.0002 & -.001 & $-1^{-5}$ & $-.005 * * *$ & .001 & -.003 & -.001 \\
\hline $\begin{array}{l}\text { Wealth } \\
\text { Total } \\
\text { Wealth }^{2}\end{array}$ & $1.76^{-7} * * *$ & $1.14^{-6 * * *}$ & $7.64^{-9} * * *$ & $7.12^{-7 * *}$ & $1.02^{-6 * * *}$ & $6.68^{-7}$ & $1.27^{-6 * * *}$ \\
\hline $\begin{array}{l}\text { Gini } \\
\text { Coefficient } \\
\text { Population } \\
\text { Density }\end{array}$ & $-.126 * * *$ & $-.866 * * *$ & $-.006 * * *$ & -.108 & $-.931 * * *$ & $-.727 * *$ & $-.949 * * *$ \\
\hline $\begin{array}{l}\text { Population } \\
\text { Density }\end{array}$ & $.035^{* * *}$ & $.231 * * *$ & $.002 * *$ & $.398 * * *$ & .166 & .365 & $.231 * * *$ \\
\hline $\begin{array}{l}\text { Population } \\
\text { Density }^{2} \\
\text { Nativity }\end{array}$ & $-.001 * * *$ & $-.004 * * *$ & $-2.8^{-5 * * *}$ & $-.005 * * *$ & $-.004 * * *$ & $-.006 * * *$ & $-.004 * * *$ \\
\hline Northeast & -.306 & -1.60 & -.012 & $-6.71 * *$ & -.609 & 1.04 & -2.57 \\
\hline $\begin{array}{l}\text { Middle } \\
\text { Atlantic }\end{array}$ & $-.224 * * *$ & $-1.36 * *$ & $-.009 * * *$ & $-2.56 * *$ & -.434 & -1.16 & $-1.37 *$ \\
\hline Plains & -.117 & -.850 & -.004 & 1.22 & -1.61 & .550 & -1.48 \\
\hline Great Lakes & -.019 & .187 & $-1.0^{-4}$ & -2.34 & 1.01 & .900 & -.304 \\
\hline Southeast & Reference & Reference & Reference & Reference & Reference & Reference & Reference \\
\hline Southwest & $-.210 *$ & -1.35 & $-.010 *$ & -.551 & $-2.92 *$ & -1.34 & $-1.95^{*}$ \\
\hline $\begin{array}{l}\text { Far West } \\
\text { Birth } \\
\text { Decade }\end{array}$ & .987 & 5.99 & .046 & $9.85 * * *$ & 5.21 & 4.72 & 2.38 \\
\hline $1800 \mathrm{~s}$ & -.527 & -3.88 & -.024 & $-8.93 * * *$ & -1.96 & & -3.96 \\
\hline $1810 \mathrm{~s}$ & .033 & .537 & .002 & -2.81 & 3.97 & & .139 \\
\hline $1820 s$ & -.215 & -1.42 & -.010 & -3.00 & .057 & & -1.67 \\
\hline $1830 s$ & -.017 & -.058 & $-5.0^{-4}$ & -.983 & .710 & 2.94 & -.324 \\
\hline $1840 \mathrm{~s}$ & Reference & Reference & Reference & Reference & Reference & Reference & Reference \\
\hline $\begin{array}{l}\text { 1850s } \\
\text { Family Size }\end{array}$ & $-.234 * * *$ & $-1.41 * * *$ & $-.010 * * *$ & $-2.03 * * *$ & -.711 & -.671 & $-1.02 * *$ \\
\hline Family Size & 1.38 & $9.39 * *$ & $.060 *$ & 1.06 & $11.04 * * *$ & 1.44 & $10.81 * * *$ \\
\hline Family Size ${ }^{2}$ & .012 & $.084^{* *}$ & $.001 * * *$ & $.190 * * *$ & .039 & .151 & $.083 *$ \\
\hline $\mathrm{N}$ & 9,058 & 9,058 & 9,058 & 4,616 & 4,442 & 3,265 & 5,793 \\
\hline $\mathrm{R}^{2}$ & .1958 & .4032 & .4177 & .4150 & .3754 & .4490 & .3189 \\
\hline
\end{tabular}

Source: See Table 1. 
Three paths of inquiry are considered when examining late $19^{\text {th }}$ and early $20^{\text {th }}$ century black and white weights. First, weight is related to wealth through absolute wealth holdings and relative wealth inequality. Across the $19^{\text {th }}$ century US, weights increased in average state wealth holdings at a decreasing rate and was inversely related to wealth inequality, indicating that better current net nutrition improved at a decreasing rate with wealth. Moreover, weight was inversely related to inequality, which limited access to nutrition among poor individuals (Table 2). Through the absolute wealth channel, weight increases in wealth at a decreasing rate because the last dollar spent on health and nutrition by a poor person has a greater impact on weight than the last dollar spent on nutrition by a wealthy person (Steckel, 1983). On the other hand, through the wealth inequality pathway, weight decreases with wealth inequality because greater inequality forecloses poorer individuals from access to nutrition. These inequality results are important because in combination with previous findings, height, BMI, and weight increased in wealth at a decreasing rate and were inversely related to inequality (Steckel, 1983; Carson, 2009a; Carson, 2010; Carson, 2013).

Second, $19^{\text {th }}$ century weights were positively related with average household size, and additional family members increased labor specialization and agricultural productivity, offsetting increased demands on household resources associated with additional family members (Table 2; Edwards and Grossman, 1978, pp. 38-39; Atack and Bateman, 1987, p. 56, Becker, 1981, pp. 97 and 102). To measure the relationship between weight and family size, individual weight is ideally linked to an individual's own family size. However, these linkages for the late $19^{\text {th }}$ century are not available; therefore, average family size by state is used in their stead. Average state family size from census records reflects economic and social needs, and given local agricultural and economic conditions, the effect of state's average family size reflects the 
needs of local labor needs. ${ }^{2}$ Moreover, defining a family is a cultural as well as a socioeconomic institution, and households historically chose the number of members needed based on internal labor needs. Given this $19^{\text {th }}$ century rural-urban difference, rural family needs were different from urban family size needs. The relationship between weight and family size may also have worked in reverse direction. Weight measures current net nutrition and stronger individuals may have had greater weight and were better able to support larger families. In sum, weight was positively and independently related to family size, indicating that greater resource demands placed on household net nutrition were offset by greater labor productivity associated with additional family members.

Third, weight is also related to state population density, and because greater population density may have led to dietary stress unique to urban areas, isolating the absolute weight-wealth relationship requires accounting for urbanization (Steckel, 1995; Carson, 2010). Weights increased at a decreasing rate in population density, and maximum weight was reached at 17.50 persons per square mile, which is approximately equal to the population density of Alabama and Mississippi. Part of the weight-density population relationship may be associated with the effects of being in close proximity to water transportation systems, which increased exposure to disease. Close proximity to trade routes also reflects exposure to trade, migration, and markets, which increased the relative price of food in urban centers (Komlos, 1987).

Other patterns are consistent with expectations. Nineteenth century weights were related to ethnic status, and across the distribution, dark and light African-American complexions had

\footnotetext{
${ }^{2}$ Because individual household size is not available, this explanation relies on the survivorship principle that posits that if a particularly plant size is efficient in the market place, all plant sizes in the market place will adapt this technology and converge on this plant size (Stigler, 1958).
} 
greater weights than whites. Much has been written about the $19^{\text {th }}$ century 'mulatto stature advantage' (Steckel, 1979; Margo and Steckel, 1982; Margo and Steckel, 1992; Bodenhorn, 2002; Carson, 2008; Carson, 2009c), and whites and light-complexioned blacks had taller statures than darker complexioned blacks. However, for both BMIs and weight, darker complexioned blacks had heavier weights than fairer complexioned whites and lighter complexioned African-Americans (Carson, 2012b; Carson, 2015c). Part of heavier black weights is biological, and blacks have greater protein in their muscle tissue, and for the same tissue volume, muscle is heavier than fat (Wagner and Heyward, 2000). ${ }^{3}$

Nineteenth century weights were positively related to height. For both blacks and whites, each additional inch in height was associated with 3.50 pounds or two percent heavier weight, and the weight-height relationship is robust across the weight distribution. After controlling for height, dark and light complexioned black weights were five and three percent greater than white weights. Weight variation was sensitive to socioeconomic status, and $19^{\text {th }}$ century farmers and unskilled workers were taller and had greater BMIs across the stature and BMI distributions than workers in other occupations (Carson, 2015b; Carson 2015d).

Diets, disease climates, and work intensity varied with residence and after controlling for wealth and inequality, weights in the rural South were greater than other regions within the US. Individuals from Southern states had greater weights than elsewhere within the US, due in part, to greater agricultural productivity. Diets in the South were, therefore, rich in calories and animal proteins, indicating that after work requirements are accounted for, weights in the South provided more net calories than elsewhere within the US (Hilliard, 1972). The South was also

\footnotetext{
${ }^{3}$ This post-obesity epidemic complexion pattern may have changed if whites put on more weight than blacks in recent decades.
} 
more rural than other regions within the US, and heavier Southern weight indicates that rural Southern current net nutrition offset calories required for work and to fend off disease. In the late $19^{\text {th }}$ and early $20^{\text {th }}$ centuries, the Northeast was the most industrialized, and Northeastern weights were lower than elsewhere within the US. In sum, weight was related with $19^{\text {th }}$ century demographics, residence, and socioeconomic conditions, and throughout life, statures, BMIs, and weight increased in wealth and population densities at decreasing rates and was inversely related with inequality.

\section{Black and White Demographics, Occupations, and Weights: A Sensitivity Analysis}

Collective and joint relationships between weight, demographics, socioeconomic status, wealth, and inequality are also noteworthy. Regression coefficients account for how individual characteristics are related to individual characteristics. They do not, however, account for how a group of variables are related to a dependent variable. For example, a single occupation coefficient—such as farming — is related to weight, but its coefficient does not represent how weight collectively varied with occupations. Sensitivity analysis accounts for how a dependent variable responds to collective effects and provides a measure for how the response variable changes with a set of characteristics. Unrestricted and restricted models for $19^{\text {th }}$ century weight are presented in Table 3. Model 1 includes all available characteristics, such as height, complexion, age, and period received (Leamer, 1983; Leamer 2010; Angrist and Pishke, 2010). Subsequent models exclude characteristics to account for the magnitude for how weight varied with collective effects. 
Table 3, Sensitivity Analysis for Weight by Demographics, Socioeconomic Status, Wealth, and Inequality

\begin{tabular}{|c|c|c|c|c|c|c|c|c|c|c|}
\hline & Model 1 & Model 2 & Model 3 & Model 4 & Model 5 & Model 6 & Model 7 & Model 8 & Model 9 & Model 10 \\
\hline Intercept & $\begin{array}{c}- \\
81.91^{* * *}\end{array}$ & $\begin{array}{c}136.35^{* *} \\
*\end{array}$ & $\begin{array}{c}\text { Race } \\
\text { Omitted }\end{array}$ & $\begin{array}{c}\text { Age } \\
\text { Omitted } \\
- \\
106.3^{* * *}\end{array}$ & $\begin{array}{l}\text { Occupatio } \\
\text { n Omitted } \\
-83.51^{* * *}\end{array}$ & $\begin{array}{l}\text { Wealth } \\
\text { Omitted }\end{array}$ & $\begin{array}{c}- \\
107.37 * * \\
*\end{array}$ & $\begin{array}{l}\text { Nativity } \\
\text { Omitted }\end{array}$ & $\begin{array}{c}\text { Birth } \\
\text { Period } \\
\text { Omitted } \\
- \\
83.89^{* * *}\end{array}$ & $\begin{array}{l}\text { Family } \\
\text { Size } \\
\text { Omitted } \\
-91.20\end{array}$ \\
\hline $\begin{array}{l}\text { Height } \\
\text { Inch } \\
\text { Ethnicity }\end{array}$ & $3.37 * * *$ & & $3.11 * * *$ & $3.68 * * *$ & $3.37 * * *$ & $3.37 * * *$ & $3.38 * * *$ & $3.37 * * *$ & $3.38 * * *$ & $3.36 * * *$ \\
\hline Black & $8.07 * * *$ & $4.26 * * *$ & & $8.20 * * *$ & $8.13^{* * *}$ & $8.02 * * *$ & $7.99 * * *$ & $8.12 * * *$ & $8.05^{* * *}$ & $8.04^{* * *}$ \\
\hline Mixed-race & $5.64 * * *$ & $3.69 * * *$ & & $5.60 * * *$ & $5.64 * * *$ & $5.59 * * *$ & $5.22 * * *$ & $5.66 * * *$ & $5.55 * * *$ & $5.61 * * *$ \\
\hline $\begin{array}{l}\text { White } \\
\text { Ages }\end{array}$ & $\begin{array}{c}\text { Referenc } \\
\text { e }\end{array}$ & Reference & $\begin{array}{c}\text { Referenc } \\
\text { e }\end{array}$ & $\begin{array}{c}\text { Referenc } \\
\text { e }\end{array}$ & Reference & $\begin{array}{c}\text { Referenc } \\
\text { e }\end{array}$ & Reference & $\begin{array}{c}\text { Referenc } \\
\text { e }\end{array}$ & $\begin{array}{c}\text { Referenc } \\
\text { e }\end{array}$ & $\begin{array}{c}\text { Referenc } \\
\text { e }\end{array}$ \\
\hline 14 & $\begin{array}{c}- \\
17.67^{* * *}\end{array}$ & $-31.80 * * *$ & $\begin{array}{c}- \\
17.66^{* * *}\end{array}$ & & $-17.61 * * *$ & $\begin{array}{c}- \\
17.64 * * *\end{array}$ & $-17.17 * * *$ & $\begin{array}{c}- \\
17.70^{* * *}\end{array}$ & $\begin{array}{c}- \\
17.99 * * *\end{array}$ & $\begin{array}{c}- \\
17.66^{* * *}\end{array}$ \\
\hline 15 & $\begin{array}{c}- \\
18.33^{* * *}\end{array}$ & $-29.78 * * *$ & $\begin{array}{c}- \\
18.18^{* * * *}\end{array}$ & & $-18.30 * * *$ & $\begin{array}{c}- \\
18.28^{* * *}\end{array}$ & $-17.79 * * *$ & $\begin{array}{c}- \\
18.38^{* * *}\end{array}$ & $\begin{array}{c}- \\
18.80^{* * * *}\end{array}$ & $\begin{array}{c}- \\
18.38 * * *\end{array}$ \\
\hline 16 & $\begin{array}{c}- \\
13.94^{* * *}\end{array}$ & $-22.10 * * *$ & $\begin{array}{c}- \\
14.02^{* * *}\end{array}$ & & $-13.89 * * *$ & $\begin{array}{c}- \\
13.93^{* * *}\end{array}$ & $-13.37 * * *$ & $\begin{array}{c}- \\
13.87^{* * *}\end{array}$ & $\begin{array}{c}- \\
14.65^{* * *}\end{array}$ & $\begin{array}{c}- \\
13.93^{* * *}\end{array}$ \\
\hline 17 & $-8.84 * * *$ & $-13.65 * * *$ & $-9.22 * * *$ & & $-8.78 * * *$ & $-8.82 * * *$ & $-8.31 * * *$ & $-8.82 * * *$ & $-9.42 * * *$ & $-8.86^{* * *}$ \\
\hline $\begin{array}{l}18 \\
19\end{array}$ & $\begin{array}{l}-8.10 * * * \\
-427 * * *\end{array}$ & $\begin{array}{l}-10.85 * * * \\
-517 * * *\end{array}$ & $\begin{array}{l}-8.35 * * * \\
-466 * * *\end{array}$ & & $\begin{array}{l}-8.07 * * * \\
-423 * * *\end{array}$ & $\begin{array}{l}-8.06 * * * \\
-423 * * *\end{array}$ & $\begin{array}{l}-7.59 * * * \\
-3.92 * * *\end{array}$ & $\begin{array}{l}-8.09 * * * \\
-425 * * *\end{array}$ & $\begin{array}{l}-8.65 * * * \\
-478 * * *\end{array}$ & $\begin{array}{l}-8.07 * * * \\
-428 * * *\end{array}$ \\
\hline $22-29$ & $\begin{array}{l}\text { Referenc } \\
\text { e }\end{array}$ & Reference & $\begin{array}{c}\text { Referenc } \\
\mathrm{e}\end{array}$ & $\begin{array}{c}\text { Referenc } \\
\text { e }\end{array}$ & Reference & $\begin{array}{c}\text { Referenc } \\
\mathrm{e}\end{array}$ & Reference & $\begin{array}{c}\text { Referenc } \\
\mathrm{e}\end{array}$ & $\begin{array}{l}\text { Referenc } \\
\mathrm{e}\end{array}$ & $\begin{array}{c}\text { Referenc } \\
\mathrm{e}\end{array}$ \\
\hline $30 s$ & $1.45^{* *}$ & $1.28 *$ & $1.49 * *$ & & $1.41^{* *}$ & $1.34 * *$ & .462 & $1.40 * *$ & $1.99 * * *$ & $1.53 * *$ \\
\hline $40 s$ & $3.27 * * *$ & $2.70 *$ & $3.85 * * *$ & & $3.25 * *$ & $3.10 * * *$ & 1.45 & $3.26 * *$ & $3.18 * * *$ & $3.42 * * *$ \\
\hline $\begin{array}{l}50 \text { s } \\
\text { Occupation }\end{array}$ & 1.99 & -.535 & 2.28 & & 2.02 & 1.80 & -.529 & 1.96 & $2.27^{*}$ & 2.17 \\
\hline Non- & Referenc & Reference & Referenc & Referenc & Reference & Referenc & Reference & Referenc & Referenc & Referenc \\
\hline
\end{tabular}




\begin{tabular}{|c|c|c|c|c|c|c|c|c|c|c|}
\hline $\begin{array}{l}\text { Agricultura } \\
l\end{array}$ & $\overline{\mathrm{e}}$ & & $\overline{\mathrm{e}}$ & $\overline{\mathrm{e}}$ & & $\overline{\mathrm{e}}$ & & $\overline{\mathrm{e}}$ & $\overline{\mathrm{e}}$ & $\overline{\mathrm{e}}$ \\
\hline $\begin{array}{l}\text { Farmer \& } \\
\text { Laborer } \\
\text { Wealth }\end{array}$ & $1.06^{* *}$ & $1.70 * * *$ & $2.10 * * *$ & .553 & & $1.01 *$ & $2.11 * * *$ & $1.13^{* *}$ & $1.12^{* *}$ & $1.53 * * *$ \\
\hline $\begin{array}{l}\text { Total } \\
\text { Wealth }\end{array}$ & -.001 & -.001 & -.002 & -.002 & -.001 & & -.002 & -.001 & -.001 & $-.003 * * *$ \\
\hline $\begin{array}{l}\text { Total } \\
\text { Wealth }\end{array}$ & $1.14^{-6 * * *}$ & $1.34^{-6 * * *}$ & $8.83^{-7} * * *$ & $1.0^{-6}$ & $1.15^{-6 * * *}$ & & $-5.46^{-7}$ & $1.14^{-6 * * *}$ & $1.18^{-6 * * *}$ & $8.23^{-7} * * *$ \\
\hline $\begin{array}{l}\text { Gini } \\
\text { Coefficient } \\
\text { Population }\end{array}$ & $-.866 * * *$ & $-.851 * *$ & $-.826 * *$ & $-.796 * *$ & $-.812 * * *$ & & $1.19 * * *$ & $-.910 * * *$ & $-.889 * * *$ & .206 \\
\hline $\begin{array}{l}\text { Population } \\
\text { Density }\end{array}$ & $.231^{* * *}$ & .001 & $.229 * * *$ & $.171^{* * *}$ & $.229 * * *$ & $.199 * * *$ & & $.260 * * *$ & $.235 * * *$ & $.136 * * *$ \\
\hline $\begin{array}{l}\text { Population } \\
\text { Density }^{2} \\
\text { Nativity }\end{array}$ & $-.004 * * *$ & $-.003 * * *$ & $-.004 * * *$ & $-.003 * * *$ & $-.004 * * *$ & $-.003 * * *$ & & $-.005 * * *$ & $-.004 * * *$ & $-.003 * * *$ \\
\hline Northeast & -1.60 & $-3.95^{*}$ & $-3.32 * *$ & -1.18 & -1.66 & -1.49 & -1.78 & & -1.59 & -1.52 \\
\hline $\begin{array}{l}\text { Middle } \\
\text { Atlantic }\end{array}$ & $-1.36 * *$ & $-3.24 * * *$ & $-2.51 * * *$ & -.838 & $-1.46^{* *}$ & $-1.28 * *$ & $-1.30 * *$ & & $-1.30 * *$ & $-1.26 * *$ \\
\hline Plains & -.850 & $-1.94 * *$ & $-2.43^{* *}$ & -.829 & -.904 & -.830 & -.850 & & -.851 & -.800 \\
\hline $\begin{array}{l}\text { Great } \\
\text { Lakes }\end{array}$ & .187 & $-1.85^{*}$ & $-2.77 * * *$ & .343 & .127 & .229 & .918 & & .245 & .332 \\
\hline Southeast & $\begin{array}{c}\text { Referenc } \\
\text { e }\end{array}$ & Reference & $\begin{array}{c}\text { Referenc } \\
\text { e }\end{array}$ & $\begin{array}{c}\text { Referenc } \\
\text { e }\end{array}$ & Reference & $\begin{array}{c}\text { Referenc } \\
\text { e }\end{array}$ & Reference & & $\begin{array}{c}\text { Referenc } \\
\text { e }\end{array}$ & $\begin{array}{c}\text { Referenc } \\
\text { e }\end{array}$ \\
\hline Southwest & -1.35 & .155 & -1.32 & $-2.37 * * *$ & -1.31 & $-1.40^{*}$ & $-2.17 * * *$ & & $-1.44^{*}$ & $-1.58^{*}$ \\
\hline $\begin{array}{l}\text { Far West } \\
\text { Birth } \\
\text { Decade }\end{array}$ & 5.99 & 2.43 & 6.74 & 1.17 & 5.65 & $8.84 * *$ & $16.18 * * *$ & & 6.47 & $11.33^{* * *}$ \\
\hline $1800 \mathrm{~s}$ & -3.88 & $-7.14 * * *$ & $-5.61 * *$ & -2.55 & -4.06 & -3.77 & -2.86 & -3.91 & & -3.98 \\
\hline $1810 \mathrm{~s}$ & .537 & 2.93 & .387 & $3.24 * * *$ & .417 & .831 & $3.48 *$ & .527 & & .462 \\
\hline $1820 \mathrm{~s}$ & -1.42 & -.648 & -2.01 & $1.91 * *$ & -1.46 & -1.28 & .713 & -1.40 & & -1.58 \\
\hline $1830 \mathrm{~s}$ & -.058 & 074 & -.290 & $2.04 * * *$ & -.099 & .099 & $1.25 *$ & -.022 & & -.127 \\
\hline
\end{tabular}




\begin{tabular}{|c|c|c|c|c|c|c|c|c|c|c|}
\hline 1840s & $\begin{array}{c}\text { Referenc } \\
\text { e }\end{array}$ & Reference & $\begin{array}{c}\text { Referenc } \\
\text { e }\end{array}$ & $\begin{array}{c}\text { Referenc } \\
\text { e }\end{array}$ & Reference & $\begin{array}{c}\text { Referenc } \\
\text { e }\end{array}$ & Reference & $\begin{array}{c}\text { Referenc } \\
\text { e }\end{array}$ & & $\begin{array}{c}\text { Referenc } \\
\text { e }\end{array}$ \\
\hline $\begin{array}{l}\text { 1850s } \\
\text { Family Size }\end{array}$ & $-1.41^{* * *}$ & $-2.06^{* * *}$ & $-1.08 * * *$ & $-4.71 * * *$ & $-1.43 * * *$ & $-1.45 * * *$ & $-2.21 * * *$ & $-1.41 * * *$ & & $-1.39 * * *$ \\
\hline $\begin{array}{l}\text { Family } \\
\text { Size }\end{array}$ & $9.39 * *$ & $12.09 * *$ & $9.52 * *$ & $9.42 * *$ & $9.06^{* *}$ & $-1.50 *$ & $-8.38 * *$ & $9.66^{* *}$ & $9.71^{* *}$ & \\
\hline $\begin{array}{l}\text { Family } \\
\text { Size }^{2}\end{array}$ & $.084 * * *$ & -.051 & .062 & $.089 * *$ & $.108^{* *}$ & $.106^{* * *}$ & -.002 & $.090 * * *$ & $.081^{* *}$ & \\
\hline $\mathrm{N}$ & 9,058 & 9,058 & 9,058 & 9,058 & 9,058 & 9,058 & 9,058 & 9,058 & 9,058 & 9,058 \\
\hline $\mathrm{R}^{2}$ & .4032 & .1915 & .3692 & .3674 & .4030 & .4020 & .3961 & .4026 & .4021 & .4021 \\
\hline
\end{tabular}

Source: See Table 1. 
Two important but possibly related variables associated with weight variation are height and age. During young growing ages when stature growth occurs, height and age are highly related. Sensitivity analysis helps parse the collective effects of height and age relationship with weight. First, when height is restricted in Model 2, the relationship between weight, complexion, age, and occupations vary considerably. A joint hypothesis test between weight and height also demonstrates that height is significantly related to height, $F(1,141,361)=29,250.76, p=.001$. When subsequent subsets of observable characteristics are omitted in Models 3 through 7, there is little variation between the relationships with weight characteristics, representing a causal effect between weight and height (Miller, 2005, pp. 37-38). Second, a joint hypothesis test on age demonstrates that weight is significantly related with age, $F(14,141,361)=690.55$, $p=0000$, but when age is omitted, there is less coefficient variation than when height is omitted; therefore, the relationship between weight and height was significant in weight variation. Age coefficients do not vary when weight is omitted, indicating that height but not age had the greatest relationship with weight.

\section{Assessing the Magnitude of Weight Variation with Collective Effects}

Weight values and other health measurements are sensitive to two general characteristics: choice and non-choice characteristics. For example, age and race are two characteristics over which individuals have no control; however, occupation and residence are two variables that individuals exercised considerable discretion. F-statistics test the statistical significance of a restricted set of variables, and observable demographic, occupations, and residence were jointly related with $19^{\text {th }}$ century weight variation. F-statistics do not, however, account for the 
magnitude or relative importance that each restricted set of variables had with weight changes. To account for restricted variables' magnitude with weight variation, a percentage change in the restricted model sum of squared regression $\left(\mathrm{SSR}_{\mathrm{R}}\right)$ relative to the unrestricted sum of squared regression $\left(\mathrm{SSR}_{\mathrm{U}}\right)$ is reported for each of the restricted variable subsets reported in Table 3.

$$
\% \Delta S S R=\frac{S S R_{R}-S S R_{U}}{S S R_{U}}=\frac{R_{R}^{2}-R_{U}^{2}}{R_{U}^{2}}=\% \Delta R^{2}
$$

Within the set of non-choice variables, height had the greatest relationship on the percentage change with weight variation. The percent change in weight variation when height is omitted decreases by 52.5 percent; age accounts for an 8.9 percent decrease, and race accounts for an 8.4 percent decrease. Within the set of choice variables, population density accounts for a 1.8 percent decrease in weight variation; nativity accounts for a 1.5 percent decrease in weight variation, while family size, wealth, and occupations only account for .27, .25, and .05 percent decreases in weight variation, respectively. Therefore, among non-choice characteristics, height had the greatest explanatory power with weight variation. Among choice characteristics, population density accounts for the greatest explanatory ability, and non-choice characteristics had the greatest explanatory power in $19^{\text {th }}$ century weight variation.

\section{Conclusion}

When traditional measures for economic well-being are scarce or unreliable, statures and BMIs are now well accepted measures for material welfare. However, because BMI represents the ratio of net current to net cumulative nutrition, it limits BMI's application as a measurement for net current nutrition. BMIs increase when weight in the numerator increases current net nutrition increases but BMI increases when height in the numerator is low, and these two measures represent opposing factors in BMI variation. This study demonstrates that $19^{\text {th }}$ black 
and white weights increased at a decreasing rate in average state wealth and was lower in states that had greater wealth inequality. Individual weights were heavier in states that had larger family sizes, indicating that larger family size was a biological net benefit that offset additional demands placed on household resources. As with stature and BMI, individual weight was related to population density, and an individual's weight increased in population density through 17.5 persons per square mile and decreased thereafter. Because urban diets were compromised with the separation of food consumption from food production, farmers were in close proximity to diets high in complex carbohydrates and animal proteins, whereas white collar and skilled workers in urban areas had diets with inferior net nutrition. The majority of historical weight variation was associated with combined effects of height and age, and weight differences vary considerably when uncontrollable height, age, and race are excluded. Therefore, $19^{\text {th }}$ century weights were related to complexion, socioeconomics, and residential characteristics, and weight varied the most with factors an individual had little control. 


\section{References}

Angrist, J. and J. S. Pischke. 2010. The credibility revolution in empirical economics: how better research design is taking the con out of econometrics. Journal of Economic Perspectives 24, pp. 3-30.

Atack, J., and Bateman, F., (1987). To Their Own Soil: Agriculture in the Antebellum North. Ames, Iowa: Iowa State University Press.

Becker, G. (1981). A Treatise on the Family. Cambridge: Harvard University Press.

Burkhauser Richard and John Cawley. (2008). “Beyond BMI: The Value of More Accurate Measures of Fatness and Obesity in Social Science Research.” Economics and Human Biology, 27, pp. 519-529.

Carson, Scott Alan. (2005) “The Biological Standard of Living in 19th-Century Mexico and in the American West,” Economics and Human Biology, Volume 3(3), pp. 405-419.

Carson, Scott Alan. (2007). "Mexican Body Mass Index Values in the $19^{\text {th }}$ Century American West,” Economics and Human Biology, Volume, 5(1), pp. 37-47.

Carson, Scott A. (2008). The Effect of Geography and Vitamin D on African-American Stature in the Nineteenth Century: Evidence from Prison Records. Journal of Economic History. 68(3), pp. 812-831.

Carson, Scott A. (2009a) "Racial Differences in Body-Mass Indices of Men Imprisoned in $19^{\text {th }}$ Century Texas” Economics and Human Biology 7, pp. 121-127.

Carson, Scott Alan, (2009b) "Health, Wealth and Inequality: a Contribution to the Debate about the relationship between Inequality and Health,” 42(4), Historical Methods. pp. 43-56.

Carson, Scott Alan, (2009c) “Geography, Insolation and Vitamin D in 19th Century US 
African-American and White Statures,” 46(1), Explorations in Economic History. pp. 149-159.

Carson, Scott Alan. (2010), “Wealth, Inequality, and Insolation Effects across the $19^{\text {th }}$ Century White US Stature Distribution,” Journal Homo of Comparative Human Biology, 61, pp. 467-478.

Carson, Scott Alan (2012a) “Nineteenth Century Race, Body Mass, and Industrialization: Evidence from American Prisons,” Journal of Interdisciplinary History 42, pp. 371391.

Carson, Scott Alan. (2012b). “A Quantile Approach to the Demographic, Residential, and Socioeconomic Effects on 19th Century African-American Body Mass Index Values” Cliometrica. 6(2), pp. 193-209.

Carson, Scott Alan. (2013). "Body Mass, Wealth, and Inequality in $19^{\text {th }}$ century U.S. Joining the Debate Surrounding Equality and Health.” Economics and Human Biology 11(1). pp. 9094.

Carson, Scott Alan. (2015a). “Biological Conditions and Economic Conditions: NineteenthCentury Stature on the U. S. Great Plains.” Human Nature 26, pp. 123-142.

Carson, Scott Alan. (2015b). “A Weighty Issue: Diminished $19^{\text {th }}$ Century Net Nutrition among the US Working Class.” Demography, 52. pp. 945-966.

Carson, Scott Alan. (2015c). “Biology, Complexion, and Socioeconomic Status: Accounting for 19th Century US BMIs by Race.” Australian Economic History Review. Forthcoming. Carson, Scott Alan. (2015d). "The Mexican Calorie Allocation among the Working Class in the 19th Century American West.” Essays in Economic and Business History. 26, pp. 3350. 
Case, A. and Paxson, C. (2008). Height, health, and cognitive function at older ages. American Economic Review, 98, 463-467.

Comer, James (2000) “North America from 1492 to the Present.” In Kenneth Kiple and Kriemheld Ornelas (Eds.). The Cambridge Word History of Food. Cambridge: Cambridge University Press. pp. 1304-1323.

Cummings, Richard O. 1940. The American and his Food. Chicago: University of Chicago Press.

Dawes, Laura. (2014). Childhood Obesity in America. (Cambridge: Harvard University Press).

Deaton, A. (2008). Height, health, and inequality: The distribution of adult heights in India. American Economic Review, 98, pp. 468-474.

Deaton, Angus. (2013). The Great Escape: Health, Wealth, and the Origins of Inequality.” Princeton: Princeton University Press.

Edwards, L. and Grossman, M. (1978). Children's Health and the Family. National Bureau of Economic Research.

Floud, Roderick, Kenneth Wachter, and Annabel Gregory. (1990). Height, Health, and History: Nutritional Status in the United Kingdom, 17850-1980. Cambridge: Cambridge University Press.

Fogel, Robert W. and Stanley Engerman, Time on the Cross. New York: W. W. Norton, 1974.

Fogel, R. (1994). "Economic Growth, Population Theory, and Physiology: The Bearing of Long-Term Processes on the Making of Economic Policy.” American Economic Review 84(3): 369-395. 
Herbert, P., Richards-Edwards, J., Manson, J.A., Ridker, P., Cook, N., O’Conner, G., Buring, J., and Hennekens, C. (1993) “Height and Incidence of Cardiovascular Disease in Male Physicians.” Circulation 88, pp.1437-1443.

Hilliard, Samuel B. Hog, Meat and Hoecake: Food Supply in the Old South, 1840-1860. Carbondale, IL: Southern Illinois University Press. 1972.

Hirschi, Travis and Michael Gottfredson. (1983) “Age and Explanation of Crime.” American Journal of Sociology, 89(3), pp. 552-584.

Komlos, J., (1987). The Height and Weight of West Point Cadets: Dietary Change in Antebellum America. Journal of Economic History 47, 897-927.

Komlos, J., Coclanis, P., 1997. On the Puzzling Cycle in the Biological Standard of Living: The Case of Antebellum Georgia. Explorations in Economic History 34, pp. 433-59.

Leamer, E. 2010. “Tantalus on the road to asymptopia.” Journal of Economic Perspectives 24, pp. 31-46.

Leamer, E. 1983. Let's take the con out of econometrics. American Economic Review 73, pp. 31-43.

Margo, R., and Steckel, R. (1982). Heights of American Slaves: New Evidence on Nutrition and Health. Social Science History, 6(4), pp. 516-538.

Margo, R., and Steckel, R. (1992). The Nutrition and Health of Slaves and antebellum Southern whites.” In R. W. Fogel \& S. L. Engerman, (Eds.), Without Consent or Contract: Conditions of Slave Life and the Transition to Freedom, (pp. 508-521). New York: Norton.

Mifflin, M.D., St Jeor, ST, Hill, LA, Scott, BJ, Daugherty, SA and YO Koh (1990). “A new 
predictive equation for resting energy expenditure in healthy individuals.” American Journal of Clinical Nutrition, Vol 51, pp. 241-247.

Miller, Jane E. (2005). The Chicago Guide to Writing about Multivariate Analysis. Chicago: University of Chicago Press.

Ransom, Roger and Richard Sutch. (1977). One Kind of Freedom: The Economic Consequences of Emancipation. Cambridge: Cambridge University Press.

Shergold, Peter R. 1982. Working Class Life: The American Standard in Comparative Perspective, 1899-1913. Pittsburgh: University of Pittsburgh Press.

Sokoloff, K., and Villaflor, G. (1982). Early Achievement of Modern Stature in America. Social Science History, 6, 453-481.

Sorkin, John, Denis Muller, and Reubin Andres. 1999. "Longitudinal Change in the Heights of Men and Women: Consequential Effects on Body Mass Index.” Epidemiologic Reviews. 21, 2, pp. 247-260.

Sorkin, John, Denis Muller, and Reubin Andres. 1999. “Longitudinal Change in Height of Men and Women: Implicaitons for Interpretation of the Body Mass Index, The Baltimore Longitudinal Study of Aging.” American Journal of Epidemiology 150, 9, pp. 969-977.

Steckel, R. H. (1979). Slave Height Profiles from Coastwise Manifests. Explorations in Economic History, 16, 363-380.

Steckel, Richard (1983) “Height and Per Capita Income,” Historical Methods, 16: 1-7.

Steckel, R. H. (1995). Stature and the Standard of Living. Journal of Economic Literature 33, 1903-1940.

Stigler, George (1958). "Price and non-Price Competition, Journal of Political Economy 76, 1, pp. 149-154. 
Subranica, S. V. and Kawachi, I. (2004). "What Have We Learned So Far? Epidemiological Reviews 26, pp. 78-91.

Wagner, D. R. and V. H.Heyward, 2000. Measures of composition in blacks and whites: a comparative review. American Journal of Clinical Nutrition 71: 1392-1402.

Wahl, Jenny Bourne, 1996, “The Jurisprudence of American Slave Sales,” The Journal of Economic History, 56(1), pp. 143-169.

Wahl, Jenny Bourne, 1997, “Legal Constraints on Slave Masters: the Problem of Social Cost,” The American Journal of Legal History, 1997, pp. 1-24.

Wilkinson, R. G. and K. E. Pichett (2006). “Income Inequality and Population Health: A Review and Explanation of the Evidence. Social Science and Medicine, 62, pp. 17681784.

Zimran, Ariell (2015). “Does Sample-Selection Bias Explain the Industrialization Puzzle? Evidence from Military Enlistment in the Nineteenth-Century United States.” http://aez.econ.northwestern.edu/zimran_height_selection.pdf. 